\title{
Comparing the Effect of Oral Supplementation of Vitamin E, Injective Vitamin $E$ and Selenium or Both during Late Pregnancy on Production and Reproductive Performance and Immune Function of Dairy Cows and Calves
}

\author{
Farokh Kafilzadeh, ${ }^{1}$ Habibollah Kheirmanesh, ${ }^{1}$ Hamed Karami Shabankareh,, \\ Mohhamad Reza Targhibi, ${ }^{1}$ Elaheh Maleki, ${ }^{1}$ Mahdi Ebrahimi, ${ }^{2}$ and Goh Yong Meng ${ }^{2,3}$ \\ ${ }^{1}$ Department of Animal Science, Faculty of Agriculture, Razi University, Kermanshah, Iran \\ ${ }^{2}$ Department of Veterinary Preclinical Sciences, Faculty of Veterinary Medicine, Universiti Putra Malaysia (UPM), \\ 43400 Serdang, Selangor, Malaysia \\ ${ }^{3}$ Institute of Tropical Agriculture, Universiti Putra Malaysia, 43400 Serdang, Selangor, Malaysia \\ Correspondence should be addressed to Goh Yong Meng; ymgoh@upm.edu.my
}

Received 28 February 2014; Revised 13 May 2014; Accepted 20 May 2014; Published 18 June 2014

Academic Editor: Joaquin Sanchez

Copyright (C) 2014 Farokh Kafilzadeh et al. This is an open access article distributed under the Creative Commons Attribution License, which permits unrestricted use, distribution, and reproduction in any medium, provided the original work is properly cited.

The object of this study was to determine the effect of prepartum supplementation of vitamin $\mathrm{E}$ with or without injective vitamin $\mathrm{E}$ and selenium (Se) on productive and reproductive performances and immune function in dairy cows. Sixty multiparous Holstein dairy cows were divided randomly into three groups at the end of gestation. Cows in each group received one of three treatments: (1) a single intramuscular (im) injection of vit. E + selenium 3 weeks prepartum; (2) daily supplementation of oral vit. E given from 3 weeks prepartum to parturition; (3) injective vit. E + Se with daily supplementation of oral vit. E. Blood samples were collected from cows at calving and from calves at 0 and 7 days of age. Concentration of IgG in serum of cows and calves as well as in colostrum was determined. No significant differences among treatments occurred in the concentrations of IgG, animal, and calf production and reproduction performance. Due to the lack of significant difference between injection and oral supplementation, it is recommended to replace the injection with oral supplementation.

\section{Introduction}

Most diseases in dairy cows occur at or just after calving, which is a period associated with immune suppression, resulting in an increased susceptibility to infections $[1,2]$. Prepartum immune suppression is multifactorial but is associated with endocrine changes and decreased intake of critical nutrients [3]. Vitamin $\mathrm{E}$ is a fat-soluble vitamin and is not synthesized in the rumen. The vitamin $\mathrm{E}$ requirement must therefore be provided in the field. However, the vitamin $\mathrm{E}$ content of the basal diet is highly variable and is not known in most situations. Although vitamin $\mathrm{E}$ content is high in fresh grass, it markedly reduces during storage and conservation [4]. Therefore, NRC [5] recommends that the total vitamin E requirement should be given via dietary supplements when conserved forages are fed and that extra supplementation may be useful during periods of immune suppression, such as around calving. Vitamin E and Se are essential micronutrients that share a common biological role as antioxidants $[6,7]$. The vitamin $\mathrm{E}$ ( $\alpha$-tocopherol) status of dairy cows is one important component of a well-functioning immune system because of its antioxidant effects on cows [8$10]$ and young dairy calves [11, 12]. At parturition, plasma concentrations of vitamin $\mathrm{E}$ were found to decrease by $47 \%$ [13], because of secretion of the vitamin into the udder during colostrogenesis, decreased dry matter intake (DMI) at calving, and an increased need for antioxidants during this time [13-15]. Passive transfer of colostral immunoglobulins is vital 
to short-term health and survival of neonates, and limited data suggest that inadequate transfer occurs in 10 to $25 \%$ of newborn beef calves [16]. Low serum immunoglobulins in young calves were related to increased incidence of disease [17]. Previous investigations have revealed that serum IgG concentrations decreased at parturition $[18,19]$.

Antioxidants are necessary to prevent some disorders in female reproduction [20]. Effects of Se, vitamin E, or their combination on fertility have been variable, with some studies reporting no effect [21] or an increase in fertility [22, 23]. Retained fetal membranes (RFM) occur when the placenta has not been shed within a short time after parturition. Cows with RFM have increased risks for metritis [24, 25] and mastitis [26] during early lactation. Some researchers [27] have observed a reduction in the incidence of RFM with a single injection of Se and vitamin E given approximately 21 $\mathrm{d}$ prepartum. In contrast, other researchers [23, 28, 29] have found no benefit of vitamin $\mathrm{E}$ or Se.

Smith et al. [30] were the first to report a beneficial effect of vit. E supplementation on incidence of mastitis. Feeding vit. E during dry periods until 30 days after calving resulted in $80 \%$ decrease in clinical mastitis and $60 \%$ reduction in intramammary infections [31] while Batra et al. [32] found no benefit of vit. E supplementation.

Lacetera et al. [33] reported that milk yield was higher in cows treated with Se and vitamin E than nontreated cows, but Weiss and Spears [10] showed no beneficial effect of Se or vitamin E supplementation on milk production.

Effects of Se and/or vitamin $\mathrm{E}$ on calf weight have been variable, with some studies reporting benefit effect [34, 35] and some reporting no effect $[36,37]$.

It is a common practice in all dairy farms in Iran to give an injective dose of vitamin $\mathrm{E}$ and Se 21 days prior to calving. Previous study [37] from our colleagues indicated a beneficial effect of double injection of vitamin $\mathrm{E}$ and Se (each $\mathrm{mL}$ contained $0.5 \mathrm{mg}$ Se as sodium selenite and $50 \mathrm{IU}$ of d-l- $\alpha$-tocopheryl acetate) over a single injection 21 days prepartum. However, it was not clear whether that was due to the extra vitamin E, selenium, or both. The objectives of this study were to determine the effect of prepartum dietary supplementation of vitamin $\mathrm{E}$ in addition to or without injective vitamin $\mathrm{E}+$ selenium during late pregnancy on production and reproduction performance and immune system of multiparous cows and their calves.

\section{Materials and Methods}

This study was conducted in a large commercial dairy farm in Kermanshah province in the west of Iran. The research protocol was approved by Razi University Animal Care and Use Committee. Sixty multiparous Holstein dairy cows in late gestation were randomly assigned into three groups. Cows in each group received one of three treatments: (1) a single intramuscular injection of $20 \mathrm{~mL}$ vit. $\mathrm{E}+$ selenium, 3 weeks prepartum (each $\mathrm{mL}$ contained $0.5 \mathrm{mg}$ Se as sodium selenite and 50 IU of d-l- $\alpha$-tocopheryl acetate); (2) oral supplementation of vit. E (4000 IU vit. E from d-1- $\alpha$-tocopherol acetate) given from 3 weeks prepartum to parturition; (3) injective vit.
TABLE 1: Nutrient composition of precalving and postcalving experimental diets.

\begin{tabular}{lcc}
\hline Item & Precalving & Postcalving \\
\hline $\mathrm{NE}_{1}(\mathrm{Mcal} / \mathrm{Kg} \mathrm{DM})$ & 1.52 & 1.69 \\
$\mathrm{CP}(\%)$ & 15.3 & 19.3 \\
$\mathrm{RDP}(\%)$ & 10.5 & 12.1 \\
$\mathrm{NDF}(\%)$ & 41.8 & 33.9 \\
$\mathrm{NFC} \mathrm{( \% )}$ & 36 & 39.5 \\
$\mathrm{Ca}(\%)$ & 0.71 & 0.95 \\
$\mathrm{P}(\%)$ & 0.32 & 0.4 \\
\hline
\end{tabular}

$\mathrm{NE}_{1}$ : net energy for lactation; $\mathrm{CP}$ : crude protein, $\mathrm{RDP}$ : ruminant degradable protein; NDF: neutral detergent fiber, NFC: nonfiber carbohydrate.

$\mathrm{E}+\mathrm{Se}$ plus oral vit. E. Animals were fed a total mixed ration (TMR) containing alfalfa hay, corn silage, and concentrate according to NRC [5] (Table 1).

The calves were separated immediately after birth (within $15 \mathrm{~min}$ ) and received $2 \mathrm{~L}$ of colostrum followed by feeding another $2 \mathrm{~L}$ in $8-10$ hours by a nursing bottle tube. Blood samples were collected from cows at calving and from calves at 0 and 7 days of age. All blood samples were centrifuged for serum collection and then stored at $-20^{\circ} \mathrm{C}$. Concentrations of IgG in serum and colostrum were determined by sandwich ELISA.

After parturition, the animals were moved in with the lactating herd. Monthly milk productions of animals were recorded every 15 days until 90 DIM. Calf birth weight, the mean daily gain, and weaning weights, calving to placenta expulsion, were recorded. The case definition for RFM was failure to pass the fetal membranes by $12 \mathrm{~h}$ after calving and for clinical mastitis was a producer diagnosis of abnormal milk or swelling of the udder, including cows with systemic illness attributed to mastitis, within 3 months after calving.

Duncan's multiple range tests were used to test differences between means once a significant effect of treatment was indicated by ANOVA. All statistical analyses were performed using SPSS package 16 [38]. The model used is described as follows:

$$
X_{i j}=\mu+T_{j}+\varepsilon_{i j},
$$

where $X_{i j}$ is dependent variable, $\mu$ is the overall mean, $T_{j}$ is the effect of treatment, and $\varepsilon_{i j}$ is the random error.

\section{Results and Discussion}

No significant differences among treatments occurred in the concentrations of IgG in serum and colostrum of dairy cows (Table 2). Reddy et al. [39] observed a trend for greater titer values for those given $125 \mathrm{IU}$ of vitamin $\mathrm{E}$ daily compared with cattle receiving no vitamin E. But Lacetera et al. [33] found that administration of $5 \mathrm{mg}$ of Se in sodium selenite form and $25 \mathrm{IU}$ of vitamin E/100 kg of body weight of cows did not affect plasma IgG concentrations in cows. Similarly, no change in $\operatorname{IgG}$ was observed when ewes were supplemented with vitamin E [40]. 
TABLE 2: Effect of oral supplementation of vitamin $E$ with or without injective vitamin $\mathrm{E}$ on immunoglobin concentrations $(\mathrm{mg} / \mathrm{dL})$ in blood and colostrums.

\begin{tabular}{lccc}
\hline $\begin{array}{l}\text { Immunoglobulin } \\
\text { concentration }(\mathrm{mg} / \mathrm{dL})\end{array}$ & Injection & $\begin{array}{c}\text { Treatments } \\
\text { Injections }+ \text { oral }\end{array}$ & Oral \\
\hline $\begin{array}{l}\text { Cattles blood serum at } \\
\text { parturition }\end{array}$ & $2039 \pm 39$ & $2128 \pm 40$ & $2118 \pm 38$ \\
$\begin{array}{l}\text { Calves blood serum at } \\
\text { birth }\end{array}$ & $132 \pm 17$ & $153 \pm 22$ & $129 \pm 22$ \\
$\begin{array}{l}\text { Calves blood serum at } \\
\text { day 7 }\end{array}$ & $1312 \pm 27$ & $1279 \pm 22$ & $1216 \pm 22$ \\
\begin{tabular}{l} 
Colostrum at parturition $6097 \pm 32$ \\
\hline
\end{tabular} & $6012 \pm 31$ & $6346 \pm 34$ \\
\hline
\end{tabular}

Because of placenta layer in cattle, there was no placental transfer of immunoglobulin, and the newborn calf is dependent upon colostrum for passive immunity [39]. The lack of difference in serum IgG of calves, in the present study, supplemented with both forms of vit. E could probably be due to the variation in absorptive ability among calves or to the sufficiency of vit. E used in only injective or oral supplemented groups, which could have partially masked the enhancing effect. A previous report from the same farm showed no significant differences in concentration of $\operatorname{IgG}$ in serum and colostrum. No change in colostral IgG to vit. E supplementation has been reported by others in ewes [40] and in cows [33,41].

Effect of treatment on birth weight, daily gain, and weaning weight was not significant because of the sufficiency of vitamin $\mathrm{E}$ and Se level in all experimental groups (Table 3). Cohen et al. [42] reported that precalving Se and vitamin $\mathrm{E}$ injections had no effect on calf birth weight, daily gain, and weaning weight compared with control, when cows were in marginal $(95 \mu \mathrm{g} / \mathrm{L})$ selenium status. Other investigators have also reported no significant impact of Se and/or vit. E supplementation of dams on body weight gain of their calves $[21,36,37]$.

There was no effect of treatment on milk yield, fat percentage and yield, and the incidence of clinical mastitis (Tables 4 and 5). It is generally accepted that the performance of lactating dairy cows can be affected by vitamin $\mathrm{E}$ and Se status during the parturient period $[33,43]$. Lacetera et al. [33] reported that milk production increased by $10 \%$ in cows supplemented with $25 \mathrm{IU}$ of vitamin $\mathrm{E}$ and $5 \mathrm{mg} \mathrm{Se}$ per $100 \mathrm{~kg}$ of body weight. Moeini et al. [37] also showed that milk production during 8 weeks of lactation was higher when a double injection of vitamin $\mathrm{E}$ and $\mathrm{Se}$ (each injection contained $1000 \mathrm{IU}$ vitamin $\mathrm{E}$ and $10 \mathrm{mg} \mathrm{Se}$ ) was given, but this effect was not observed when milk yield during 12 weeks was compared between cows that received a single or double dose or injective vitamin E and Se. Weiss and Spears [10] and Bourne et al. [44] found no significant effect on milk production due to vit. E supplementation.

Days open and services per conception did not differ between experimental groups (Table 5). Reports on the effects of Se, vitamin $\mathrm{E}$, or their combination with fertility are
TABLE 3: Effect of oral supplementation of vitamin $E$ with or without injective vitamin $\mathrm{E}$ on body weight of calves.

\begin{tabular}{lccc}
\hline Item & \multicolumn{3}{c}{ Treatments } \\
& Injection & Injections + oral & Oral \\
\hline Birth weight & $43.35 \pm 3.71$ & $42.55 \pm 4.34$ & $42.86 \pm 4.08$ \\
Weaning weight & $94.18 \pm 9.19$ & $89.56 \pm 12.81$ & $97.35 \pm 9.84$ \\
$\begin{array}{l}\text { Body weight gain } \\
\begin{array}{l}\text { Daily body weight } \\
\text { gain }\end{array}\end{array}$ & $50.82 \pm 9.36$ & $50.18 \pm 14.73$ & $53.30 \pm 11.7$ \\
\hline
\end{tabular}

TABLE 4: Effect of oral supplementation of vitamin $\mathrm{E}$ with or without injective vitamin $\mathrm{E}$ on milk yield in multiparous dairy cows.

\begin{tabular}{|c|c|c|c|}
\hline \multirow{2}{*}{ Item } & \multicolumn{3}{|c|}{ Treatments } \\
\hline & Injection & Injections + oral & Oral \\
\hline \multicolumn{4}{|l|}{ Milk production } \\
\hline First month & $31.44 \pm 9.31$ & $35.33 \pm 8.83$ & $36.63 \pm 7.59$ \\
\hline Second month & $32.16 \pm 9.68$ & $34.53 \pm 8.90$ & $34.79 \pm 7.06$ \\
\hline Third month & $31.29 \pm 7.74$ & $30.07 \pm 6.24$ & $33.64 \pm 7.63$ \\
\hline \multicolumn{4}{|l|}{ Fat (percentage) } \\
\hline First month & $2.728 \pm 0.64$ & $2.37 \pm 0.57$ & $2.483 \pm 0.55$ \\
\hline Second month & $2.681 \pm 0.10$ & $2.573 \pm 0.10$ & $2.501 \pm 0.06$ \\
\hline Third month & $2.721 \pm 0.53$ & $2.819 \pm 0.43$ & $2.680 \pm 0.62$ \\
\hline \multicolumn{4}{|l|}{ FCM } \\
\hline First month & $24.65 \pm 4.93$ & $26.11 \pm 4.71$ & $27.81 \pm 4.15$ \\
\hline Second month & $24.91 \pm 5.53$ & $26.41 \pm 4.36$ & $26.58 \pm 3.79$ \\
\hline Third month & $24.78 \pm 4.67$ & $24.40 \pm 3.50$ & $26.40 \pm 3.97$ \\
\hline
\end{tabular}

variable, with some studies reporting an increase in fertility $[2,22,34]$ and some reporting no effect $[37,44]$.

The reasons of these discrepancies could be related to the level of Se, interaction of Se-vit. E, and other nutrition factors as protein, energy, $\mathrm{Ca}, \mathrm{Mg}$, and $\mathrm{P}$ intake that might also influence reproduction rates [45]. Differences between studies in the amount of vit. E and/or Se administered, the period of administration, and nutritional status of the experimental animals with respect to vit. $\mathrm{E}$ and Se intake could explain some of these differential results [2].

\section{Conclusions}

Due to the lack of significant difference between treatments and ease of use of oral supplements, oral supplementation is recommended to replace the injection. No advantage of oral supplementation plus injective vitamin $\mathrm{E}$ compared to either of them alone could be due to the sufficiency of vitamin $\mathrm{E}$ in all treatments. As discussed above, the illnesses suffered after birth were suitable indicators showing good nutritional and other management conditions under which the dairy herd was kept. 
TABLE 5: Effect of oral supplementation of vitamin E with or without injective vitamin E on reproductive performance in multiparous dairy cows.

\begin{tabular}{lccc}
\hline Item & Injection & $\begin{array}{c}\text { Treatments } \\
\text { Injections + oral }\end{array}$ & Oral \\
\hline Mastitis & 2 & 1 & 2 \\
Metritis & 2 & 0 & 0 \\
Retained placenta & 0 & $143.06 \pm 47.62$ & 1 \\
Open days & $118.41 \pm 46.08$ & $3.07 \pm 1.75$ & $118.36 \pm 40.90$ \\
Service per conception & $2.00 \pm 1.28$ & $2.36 \pm 1.21$ \\
\hline
\end{tabular}

\section{Conflict of Interests}

The authors declare that there is no conflict of interests regarding the publication of this paper.

\section{References}

[1] B. A. Mallard, J. C. Dekkers, M. J. Ireland et al., "Alteration in immune responsiveness during the peripartum period and its ramification on dairy cows and calf health," Journal of Dairy Science, vol. 81, no. 2, pp. 589-595, 1998.

[2] K. Persson Waller, "Mammary gland immunology around parturition. Influence of stress, nutrition and genetics," Advances in Experimental Medicine and Biology, vol. 480, pp. 3488-3497, 2000.

[3] J. P. Goff and R. L. Horst, "Physiological changes at parturition and their relationship to metabolic disorders," Journal of Dairy Science, vol. 80, no. 7, pp. 1260-1268, 1997.

[4] K. Persson Waller, C. H. Sandgren, U. Emanuelson, and S. K. Jensen, "Supplementation of RRR- $\alpha$-tocopheryl acetate to periparturient dairy cows in commercial herds with high mastitis incidence," Journal of Dairy Science, vol. 90, no. 8, pp. 36403646, 2007.

[5] NRC, Nutrient Requirements of Dairy Cattle, National Academy Press, Washington, DC, USA, 7th edition, 2001.

[6] A. Bendich, "Antioxidant micronutrients and immune responses," Annals of the New York Academy of Sciences, vol. 587, pp. 168-180, 1990.

[7] J. S. Hogan, W. P. Weiss, K. L. Smith, L. M. Sordillo, and S. N. Williams, " $\alpha$-tocopherol concentrations in milk and plasma during clinical Escherichia coli mastitis," Journal of Dairy Science, vol. 79, no. 1, pp. 71-75, 1996.

[8] J. S. Hogan, W. P. Weiss, and K. L. Smith, "Role of vitamin E and selenium in host defense against mastitis," Journal of Dairy Science, vol. 76, no. 9, pp. 2795-2803, 1993.

[9] I. Politis, N. Hidiroglou, J. H. White et al., "Effects of vitamin E on mammary and blood leukocyte function, with emphasis on chemotaxis, in periparturient dairy cows," American Journal of Veterinary Research, vol. 57, no. 4, pp. 468-471, 1996.

[10] W. P. Weiss and J. W. Spears, "Vitamin and trace mineral effects on immune function of ruminants," in Ruminant Physiology. Digestion, Metabolism and Impact of Nutrition on Gene Expression, Immunology and Stress, K. Sejrsen, T. Hvelplund, and M. O. Nielsen, Eds., pp. 473-496, Wageningen Academic Publishers, Wageningen, The Netherlands, 2006.

[11] J. E. Cipriano, J. L. Morrill, and N. V. Anderson, "Effect of dietary vitamin E on immune responses of calves," Journal of Dairy Science, vol. 65, no. 12, pp. 2357-2365, 1982.
[12] S. D. Eicher-Pruiett, J. L. Morrill, F. Blecha, J. J. Higgins, N. V. Anderson, and P. G. Reddy, "Neutrophil and lymphocyte response to supplementation with vitamins $\mathrm{C}$ and $\mathrm{E}$ in young calves," Journal of Dairy Science, vol. 75, no. 6, pp. 1635-1642, 1992.

[13] J. P. Goff and J. R. Stabel, "Decreased plasma retinol, $\alpha$ tocopherol, and zinc concentration during the periparturient period: effect of milk fever," Journal of Dairy Science, vol. 73, no. 11, pp. 3195-3199, 1990.

[14] W. P. Weiss, D. A. Todhunter, J. S. Hogan, and K. L. Smith, "Effect of duration of supplementation of selenium and vitamin E on periparturient dairy cows," Journal of Dairy Science, vol. 73, no. 11, pp. 3187-3194, 1990.

[15] G. E. Meglia, S. K. Jensen, C. Lauridsen, and K. P. Waller, " $\alpha$-Tocopherol concentration and stereoisomer composition in plasma and milk from dairy cows fed natural or synthetic vitamin E around calving," Journal of Dairy Research, vol. 73, no. 2, pp. 227-234, 2006.

[16] L. J. Perino, "A guide to colostrum management in beef cows and calves," Veterinary Medicine, vol. 92, no. 1, pp. 75-82, 1997.

[17] A. D. McEwan, E. W. Fisher, and I. E. Selman, "Observations on the immune globulin levels of neonatal calves and their relationship to disease," Journal of Comparative Pathology, vol. 80, no. 2, pp. 259-265, 1970.

[18] J. C. Detilleux, M. E. Kehrli Jr., J. R. Stabel, A. E. Freeman, and D. H. Kelley, "Study of immunological dysfunction in periparturient Holstein cattle selected for high and average milk production," Veterinary Immunology and Immunopathology, vol. 44, no. 3-4, pp. 251-267, 1995.

[19] M. E. Kehrli Jr. and J. P. Goff, "Periparturient hypocalcemia in cows: effects on peripheral blood neutrophil and lymphocyte function," Journal of Dairy Science, vol. 72, no. 5, pp. 1188-1196, 1989.

[20] J. Fujii, Y. Iuchi, and F. Okada, "Fundamental roles of reactive oxygen species and protective mechanisms in the female reproductive system," Reproductive Biology and Endocrinology, vol. 3, article 43, 2005.

[21] S. A. Gunter, P. A. Beck, and J. M. Phillips, "Effects of supplementary selenium source on the performance and blood measurements in beef cows and their calves," Journal of Animal Science, vol. 81, no. 4, pp. 856-864, 2003.

[22] C. F. Arrehiga, O. Ortiz, and P. J. Hansen, "Effect of prepartum injection of vitamin $\mathrm{E}$ and selenium on postpartum reproductive function of dairy cattle," Theriogenology, vol. 41, no. 6, pp. 1251-1258, 1994.

[23] E. C. Segerson, G. J. Riviere, H. L. Dalton, and M. D. Whitacre, "Retained placenta of Holstein cows treated with selenium and vitamin E," Journal of Dairy Science, vol. 64, no. 9, pp. 1833-1836, 1981. 
[24] U. Emanuelson, P. A. Oltenacu, and Y. T. Gröhn, "Nonlinear mixed model analyses of five production disorders of dairy cattle," Journal of Dairy Science, vol. 76, no. 9, pp. 2765-2772, 1993.

[25] M. T. Correa, H. Erb, and J. Scarlett, "Path analysis for seven postpartum disorders of Holstein cows," Journal of Dairy Science, vol. 76, no. 5, pp. 1305-1312, 1993.

[26] P. H. Bendixen, B. Vilson, I. Ekesbo, and D. B. Åstrand, "Disease frequencies in dairy cows in Sweden. v. mastisis," Preventive Veterinary Medicine, vol. 5, no. 4, pp. 263-274, 1988.

[27] S. Eger, D. Drori, I. Kadoori, N. Miller, and H. Schindler, "Effects of selenium and vitamin E on incidence of retained placenta," Journal of Dairy Science, vol. 68, no. 8, pp. 2119-2122, 1985.

[28] M. Hidiroglou, "Mammary transfer of vitamin E in dairy cows," Journal of Dairy Science, vol. 72, no. 4, pp. 1067-1071, 1989.

[29] E. C. Segerson Jr., F. A. Murray, A. L. Moxon, D. R. Redman, and H. R. Conrad, "Selenium/vitamin E: role in fertilization of bovine ova," Journal of Dairy Science, vol. 60, no. 6, pp. 1001$1005,1977$.

[30] K. L. Smith, J. H. Harrison, D. D. Hancock, D. A. Todhunter, and H. R. Conrad, "Effect of vitamin E and selenium supplementation on incidence of clinical mastitis and duration of clinical symptoms," Journal of Dairy Science, vol. 67, no. 6, pp. 12931300, 1984.

[31] W. P. Weiss, J. S. Hogan, D. A. Todhunter, and K. L. Smith, "Effect of vitamin E supplementation in diets with a low concentration of selenium on mammary gland health of dairy cows," Journal of Dairy Science, vol. 80, no. 8, pp. 1728-1737, 1997.

[32] T. R. Batra, K. H. Singh, S. K. Ho, and M. Hidiroglou, "Concentration of plasma and milk vitamin $\mathrm{E}$ and plasma betacarotene of mastitic and healthy cows," International Journal for Vitamin and Nutrition Research, vol. 62, no. 3, pp. 233-237, 1992.

[33] N. Lacetera, U. Bernabucci, B. Ronchi, and A. Nardone, "Effects of selenium and vitamin $\mathrm{E}$ administration during a late stage of pregnancy on colostrum and milk production in dairy cows, and on passive immunity and growth of their offspring," American Journal of Veterinary Research, vol. 57, no. 12, pp. 1776-1780, 1996.

[34] J. J. Wichtel, A. L. Craigie, H. Varela-Alvarez, and N. B. Williamson, "The effect of intraruminal selenium pellets on growth rate, lactation and reproductive-efficiency in dairy cattle," New Zealand Veterinary Journal, vol. 42, no. 6, pp. 205210, 1994.

[35] D. M. Castellan, J. P. Maas, I. A. Gardner, J. W. Oltjen, and M. L. Sween, "Growth of suckling beef calves in response to parenteral administration of selenium and the effect of dietary protein provided to their dams," Journal of the American Veterinary Medical Association, vol. 214, no. 6, pp. 816-821, 1999.

[36] M. Mohri, H. A. Seifi, and J. Khodadadi, "Effects of preweaning parenteral supplementation of vitamin $\mathrm{E}$ and selenium on hematology, serum proteins, and weight gain in dairy calves," Comparative Clinical Pathology, vol. 14, no. 3, pp. 149-154, 2005.

[37] M. M. Moeini, H. Karami, and E. Mikaeili, "Effect of selenium and vitamin E supplementation during the late pregnancy on reproductive indices and milk production in heifers," Animal Reproduction Science, vol. 114, no. 1-3, pp. 109-114, 2009.

[38] SPSS, Base System Syntax Reference Guide, Release 16, SPSS, Chicago, Ill, USA, 1993.

[39] P. G. Reddy, J. L. Morrill, H. C. Minocha, and J. S. Stevenson, "Vitamin E is immunostimulatory in calves," Journal of Dairy Science, vol. 70, no. 5, pp. 993-999, 1987.
[40] J. T. Daniels, P. G. Hatfield, D. E. Burgess, R. W. Kott, and J. G. P. Bowman, "Evaluation of ewe and lamb immune response when ewes were supplemented with vitamin E," Journal of Animal Science, vol. 78, no. 10, pp. 2731-2736, 2000.

[41] M. M. Moeini, A. Kiani, E. Mikaeili, and H. K. Shabankareh, "Effect of prepartum supplementation of selenium and vitamin e on serum Se, IgG concentrations and colostrum of heifers and on hematology, passive immunity and Se status of their offspring," Biological Trace Element Research, vol. 144, no. 1-3, pp. 529-537, 2011.

[42] R. D. Cohen, B. D. King, C. Guenther, and E. D. Janzen, "Effects of prepartum parenteral supplementation of pregnant beef cow with selenium/vitamin E on cow and calf plasma selenium and productivity," The Canadian Veterinary Journal, vol. 32, pp. 113115, 1991.

[43] L. Pavlata, J. Prasek, A. Podhorsky, A. Pechova, and T. Haloun, "Selenium maternal transfer of selenium to newborn calves at different selenium concentrations in dams," Acta Veterinaria Brno, vol. 72, no. 4, pp. 639-646, 2003.

[44] N. Bourne, D. C. Wathes, K. E. Lawrence, M. McGowan, and R. A. Laven, "The effect of parenteral supplementation of vitamin E with selenium on the health and productivity of dairy cattle in the UK," Veterinary Journal, vol. 177, no. 3, pp. 381-387, 2008.

[45] J. E. Ramírez-Bribiesca, J. L. Tortora, M. Huerta, L. M. Hernández, R. López, and M. M. Crosby, "Effect of seleniumvitamin $\mathrm{E}$ injection in selenium-deficient dairy goats and kids on the Mexican plateau," Arquivo Brasileiro de Medicina Veterinaria e Zootecnia, vol. 57, no. 1, pp. 77-84, 2005. 


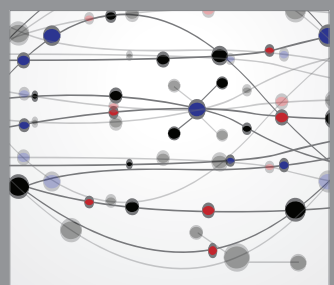

The Scientific World Journal
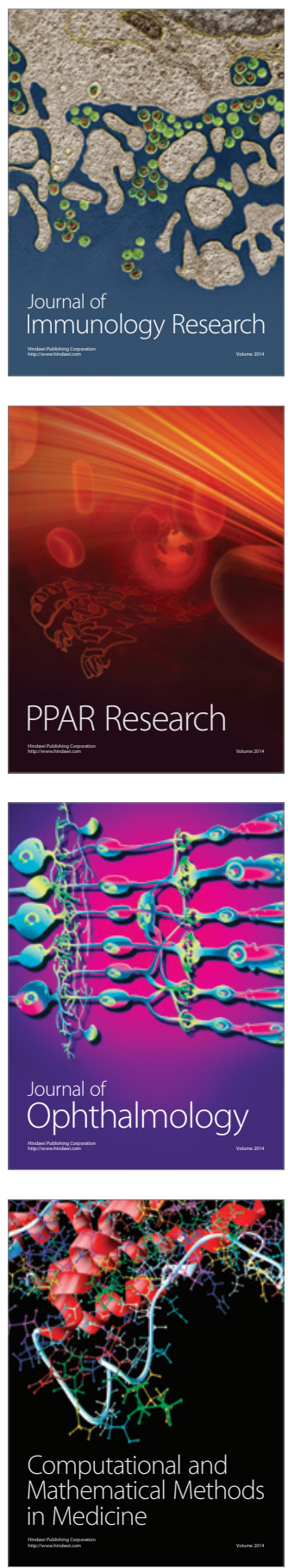

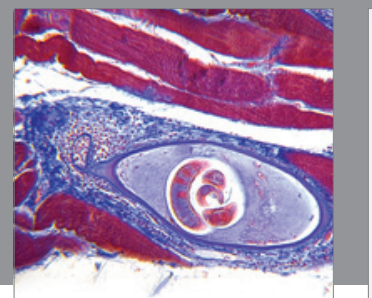

Gastroenterology

Research and Practice
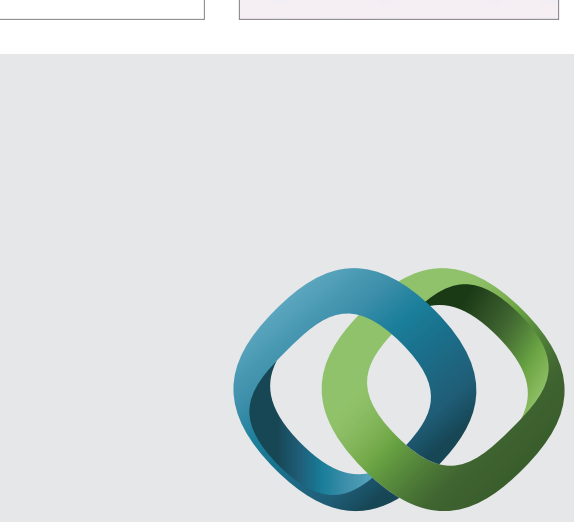

\section{Hindawi}

Submit your manuscripts at

http://www.hindawi.com
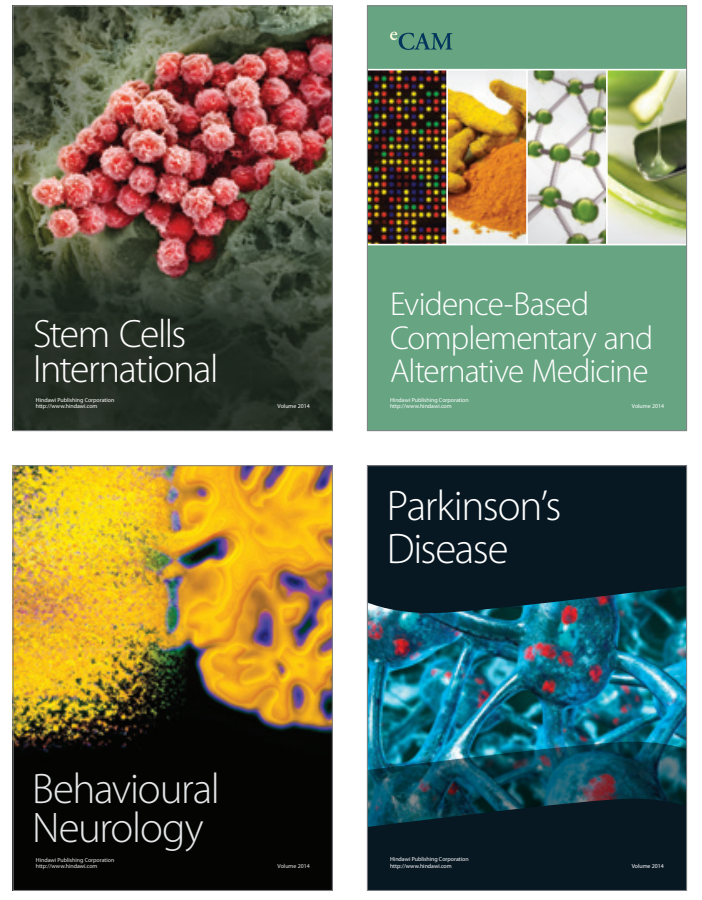
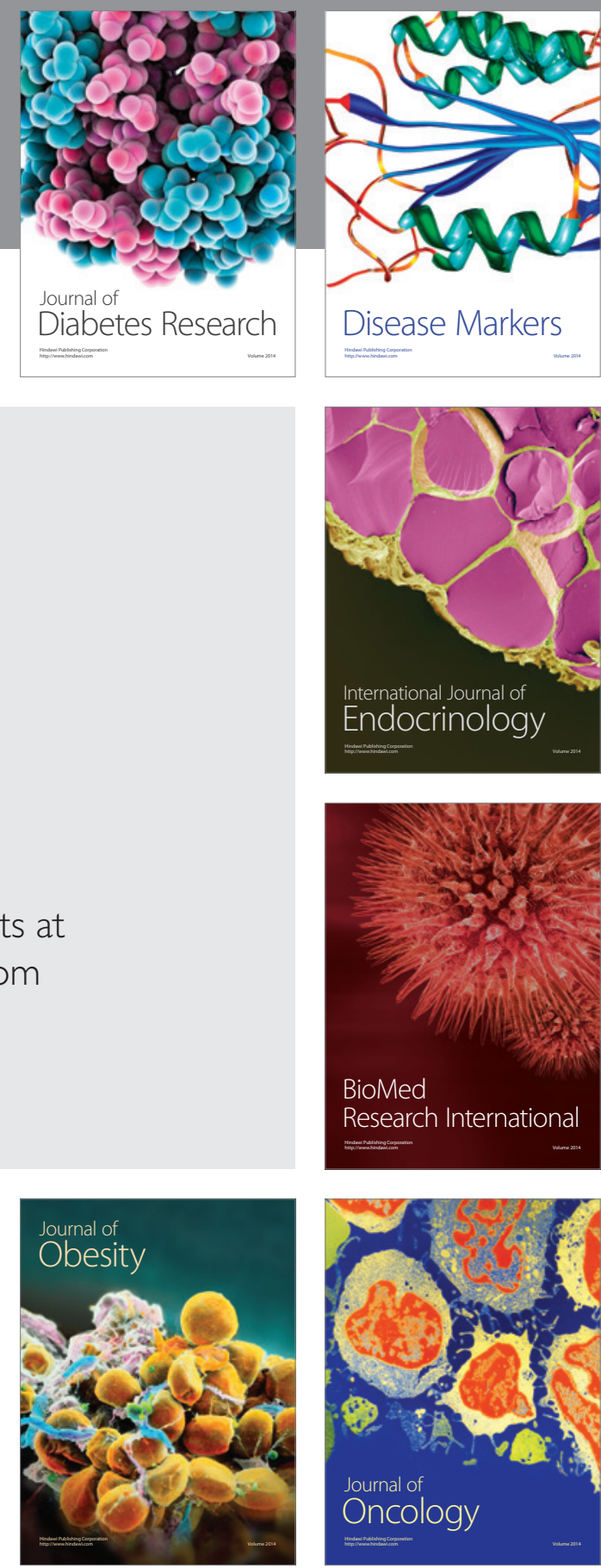

Disease Markers
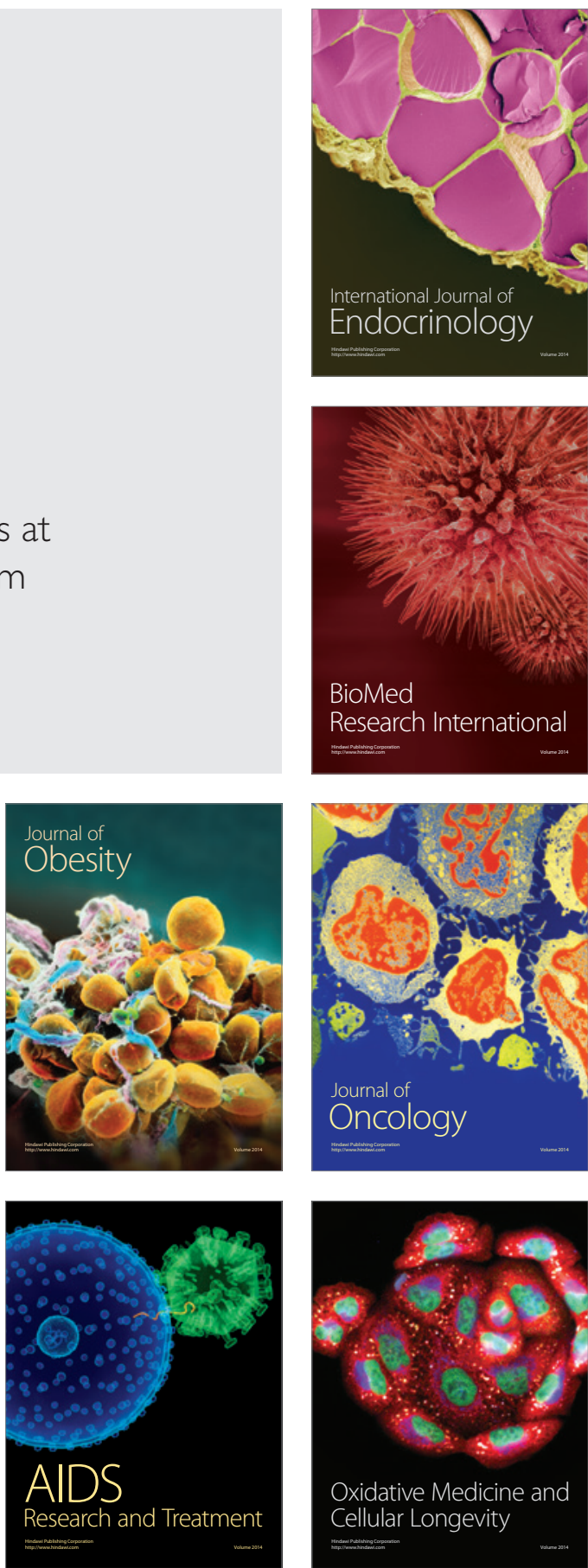